\title{
冬の気温と河川の流量
}

一一東北電力及び北海道電力株式会社管内の場合について—

荒川秀俊・堤 敬一郎

\section{Integrated Run-off and Mean Air-temperature during Winter}

\author{
By H. Arakawa and K. Tsutsumi \\ Meteorological Research Institute, Tokyo \\ (Manuscript received 26 June, 1958)
}

\begin{abstract}
Correlations between integrated run-off (in terms of hydro-electric potential out-put $\mathrm{KWh}$ ) and mean air-temperature during winter extending over the period of fifteen years are discussed for two districts in Japan. Integrated run-off during winter runs closely parallel to the mean air-temperature year by year in the Tohoku district $(r=+0.83$, see Figs. 1 and 2) whose mean air-temperature in winter is nearly $0^{\circ} \mathrm{C}$ (i.e. melting point): while no marked correlation between integrated run-off and mean air-temperature during winter exists in Hokkaido, whose mean air-temperature in winter is quite low as $-6^{\circ}-7^{\circ} \mathrm{C}$. Data for hydro-electric potential out-put shown in Tables 1 and 2 are taken from a source book published by the Ministry of International Trade and Industry, Japan.
\end{abstract}

東日本に括けるがごとく，冬期雪として降った 降水量の大部分が山間部に積雪となってのこる場 合には，電源地方の河川の流量は概ね平均気温に よって支配されるといわれている。私はこの定理 を証明するために，東北電力株式会社の管内の場 合について，追試してみたい。

福島・石巻・宮古・青森・秋田・山形の 6 つの 測候所子しくは気象台に和ける 12 月, 翌年 1 月, 2 月の月平均気温の平均をもって, 冬の東北地方 の平均気温と定義することとする。この冬の気温 は電源地带の気温よりやや高めにすぎ, 電源地带 の気温を正確には代表しないかも知れないが，第 1 近似として採用することとした。また河川の流 量としては, 通産省公益事業局発表の自流式発電 所の可能発電電力量をもってあてることとする。 元来, 可能出力とは，すべての設備が現状のまま 完全であるとして，そのときの流水量を完全に利 用して発生できる全発電力をいう。一般には（可 能発電力 $)=($ 実際発電力 $)+($ 溢水電力もしくは無効 放流電力）となる。ただし，実際発電力が認可最 大発電力よりも大きいときは，実績とのままを可 能発電力とする。
第 1 表には前述のごとくに定義された東北地方 の冬の平均気温を昭和 $17 / 18$ 年から昭和 $31 / 32$ 年

第 1 表

\begin{tabular}{c|c|c}
\hline 昭和 & $\begin{array}{c}\text { 東北地方の冬の } \\
\text { 平均気温 }\left({ }^{\circ} \mathrm{C}\right)\end{array}$ & $\begin{array}{c}\text { 東北電力株式会社 } \\
\text { の而能発電電量 } \\
\left(10^{7} \mathrm{KWh}\right)^{*}\end{array}$ \\
\hline $17 / 18$ & -0.4 & 111 \\
$18 / 19$ & -0.7 & 116 \\
$19 / 20$ & -2.7 & 110 \\
$20 / 21$ & -0.1 & 133 \\
$21 / 22$ & -0.5 & 136 \\
$22 / 23$ & -0.2 & 129 \\
$23 / 24$ & +3.0 & 176 \\
$24 / 25$ & +0.8 & 157 \\
$25 / 26$ & 0.0 & 139 \\
$26 / 27$ & +0.4 & 147 \\
$27 / 28$ & -0.5 & 125 \\
$28 / 29$ & +1.4 & 146 \\
$29 / 30$ & +0.7 & 121 \\
$30 / 31$ & +0.9 & 139 \\
$31 / 32$ & -0.1 & 131 \\
\hline 平均 & +0.1 & 134 \\
\hline
\end{tabular}

* 通産省公益事業局発表 (昭和 33 年 3 月 31 日現 在設備に対するもの) 
まで毎冬の分につき示して山る。また同じ年度の 12 月， 1 月， 2 月の東北電力株式会社の自流式発 電所の可能発電電力量 (昭和 33 年 3 月 31 日現 在設備）をも併せ記した。第 1 表の資料にもとず いて，年度別の気温と流量との経年变化を第 1 図 に示してめるが，気温と流量とはいちがるしく平 行して変化していることがわかる。さらに気温と 流量との相関係数を計算してみると，実に +0.83 となり，確実に気温と流量とは正の相関をもって いることが推論できるのである。
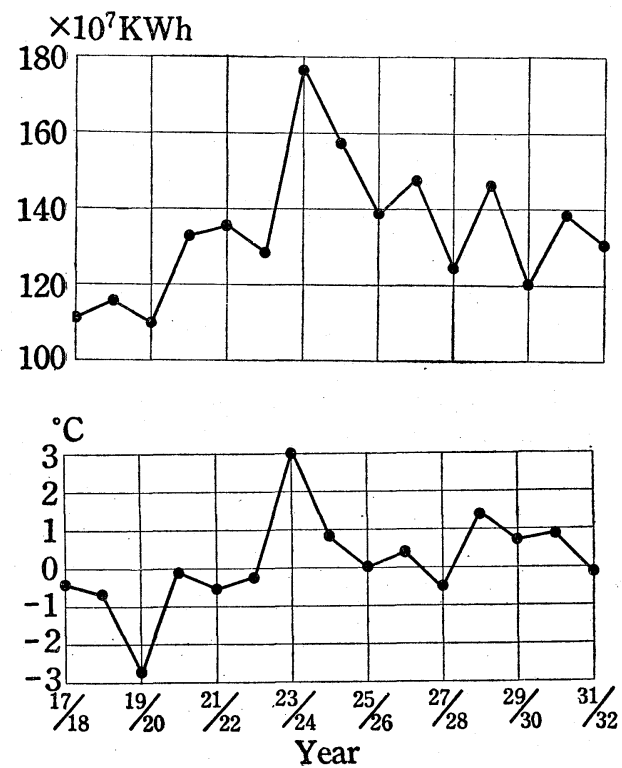

Fig. 1. Integrated run-off and mean air-temperature during winter for the Tohoku District, 1942/43 1956/57.

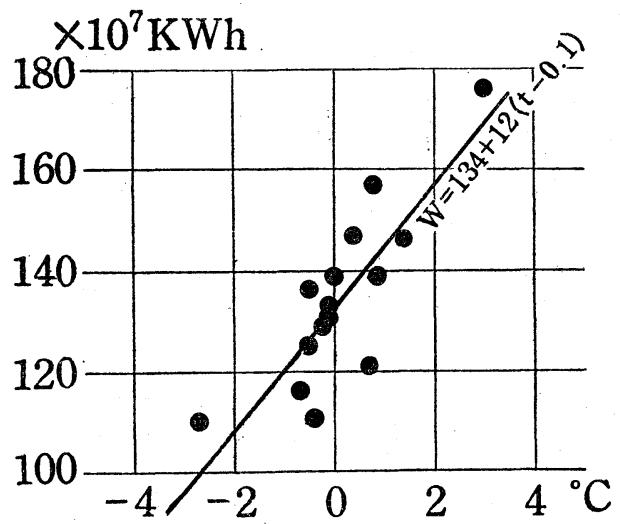

Fig. 2. Scatter diagram of relation between runoff and mean air-temperature for the Tohoku District.
すなわら，冬季の平均気温が零度より少し低目 で，積雪となつて降水量が山間にたまっているよ うな地域における河川の流量は，その冬の気温の 昇降に応ずるごとく増減する傾向があることがわ かる。

$\times 10^{6} \mathrm{KWh}$
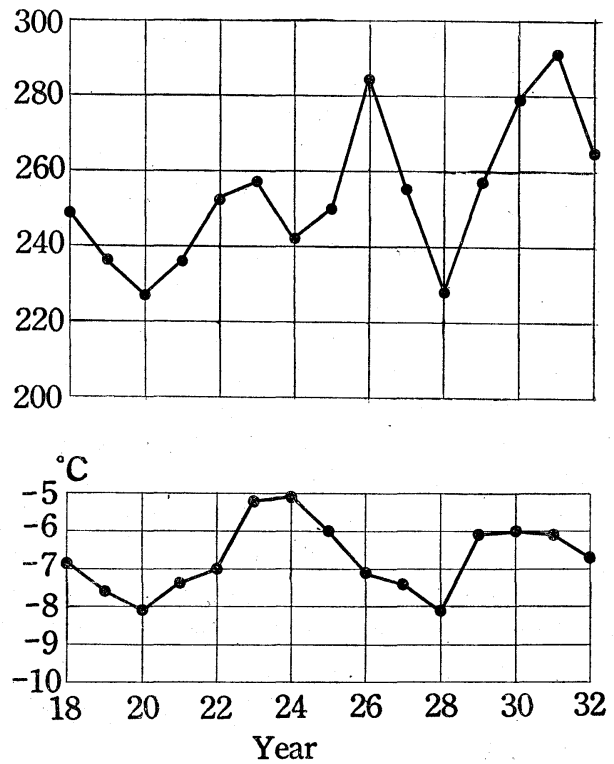

Fig. 3. Integrated run-off and mean air-temperature during winter in Hokkaido, 1943 1957.

第 2 表

\begin{tabular}{c|c|c}
\hline 昭和 & $\begin{array}{c}\text { 北海道の冬の } \\
\text { 平均気温 }\left({ }^{\circ} \mathrm{C}\right)\end{array}$ & $\begin{array}{c}\text { 北海道電力株式会社 } \\
\text { 苛能発電電力量 } \\
\left(10^{6} \mathrm{KWh}\right)\end{array}$ \\
\hline 18 & -6.9 & 249 \\
19 & -7.6 & 236 \\
20 & -8.1 & 227 \\
21 & -7.4 & 236 \\
22 & -7.0 & 252 \\
23 & -5.2 & 257 \\
24 & -5.1 & 242 \\
25 & -6.0 & 250 \\
26 & -7.1 & 284 \\
27 & -7.4 & 255 \\
28 & -8.1 & 228 \\
29 & -6.1 & 257 \\
30 & -6.0 & 279 \\
31 & -6.1 & 291 \\
32 & -6.7 & 265 \\
\hline 平均 & -6.7 & 254 \\
\hline
\end{tabular}


な技東北電力の冬 $(12 \cdot 1 \cdot 2$ 月) の可能発電電 力量 $\left(10^{7} \mathrm{KWh}\right.$ 単位) $W$, 東北地方の冬の平均 温度 $\left({ }^{\circ} \mathrm{C}\right.$ 単位)を $t$ として, regression equation を作ると

$$
W=134+12(t-0.1)
$$

となる。即ち冬の平均温度が $1^{\circ} \mathrm{C}$ 高い年には，可 能発電電力量はひと冬に付 $12 \times 10^{7} \mathrm{KWh}$ 增とな ることをしめす。第 2 図には regression equation と実測値の関係が説明してある。

な和北海道電力株式会社管内の分について子同 様な論法で攻究してみよう。北海道の内陸の冬の 平均気温をしめす目安として，旭川と带広での 1 月・ 2 月・ 3 月の月平均気温の平均家採用括る そとする。また通産省発表の北海道電力株式会社 の可能発電電力量の第 4 四半期分をるって, 河川 の流量をしめす目安とした。な拈採用した期間は 前々同じく昭和 17 年度から 31 年度 (即ち昭和 18 年 $1 \cdot 2 \cdot 3$ 月分方占昭和 32 年 $1 \cdot 2 \cdot 3$ 月分） での 15 箇年間である。因みに北海道では 3 月に 入っても融雪办本格的には稆こらない上に，河川
の流量は 12 月よりも 3 月の方が少ないので, 東 北電力の分より 1 箇月ずらして統計することとし た。第 3 困は第 2 表の資料をグラフにしたもので あるが，北海道電力管内の冬の上うに氷点下数度 そいうようなところでは，冬のあいだ少しくらい 䁔かくとも，雪はとけにくく，河川の流量加增す ようなことは期待できないとい方ると思う。(平均 気温と流量との相関係数は +0.46である。)

要するに，従来電力界では，冬季における河川 の流量は気温の昇降に伴って増減すると考えられ ていたが，このことは本州東部におけるが如く， 冬季の平均気温が水点か, 水点よりわずか低い地 域（例えば東北電力管内の分）においては正確に 成立つけれども，冬季の平均気温が水点下数度と いうような北海道電力管内では必らずしも成立し ない。融雪が丁度 $0^{\circ} \mathbf{C}$ でおこるという物理的制 約と, 気温の変動幅は一般に数度以内であること とを考慮すれば，この事実は容易にうなずけるこ とである。 